\title{
Heleieth Saffioti, uma pioneira dos estudos feministas no Brasil
}

\author{
Luzinete Simões Minella \\ Universidade Federal de Santa Catarina
}

\begin{abstract}
A REF tem apresentado, desde 1998, entrevistas com pesquisadoras/es da área dos estudos feministas e de gênero e, entre mais de duas dezenas de entrevistadas/os, na maioria mulhe-res, contam-se poucas brasileiras. Quando fechávamos o último número do volume 18/2010 da Revista, recebemos a notícia da morte de Heleieth Saffioti e, consternadas, só pudemos incluir nele uma nota sobre seu falecimento. Heleieth foi pioneira dos estudos feministas na academia brasileira e, por sua atuação na formação acadêmica na área, que se estendeu por mais de quatro décadas, pela importância e significado de sua produção, é uma das vozes que não podemos deixar de divulgar nas páginas da revista, em reverência à sua memória.

Assim, agradecemos a Zahidé Muzart, da Editora Mulheres, e a Miriam Grossi e Rozeli Porto, organizadoras da coletânea Depoimentos: trinta anos de pesquisas feministas brasileiras sobre violência, a oportunidade de reeditarmos a entrevista de Heleith Saffioti constante daquela publicação. A entrevista foi realizada em julho de 2004, pelas então doutorandas do Programa de Pós-Graduação em Antropologia Social Juliana Cavilla Mendes e Simone Becker, como parte do projeto de pesquisa "Mapeamento nacional de pesquisas e publicações sobre violências contra mulheres", desenvolvido no Núcleo de Identidades de Gênero e Subje-tividades (NIGS/ UFSC), sob a coordenação de Miriam Pillar Grossi.
\end{abstract}


O material a seguir, como as/os leitoras/es poderão perceber, traz um rico relato da trajetória de vida e formação de Heleieth Saffioti. Nele se reflete parte importante da história das ciências sociais no Brasil e, particularmente, das dificuldades, acasos e superações implicados no ingresso das mulheres nesse campo. 